ON THE RECORD

\section{' We need to turn scientists back into the rock stars they are.")}

Morgan Spurlock is making a movie of The Republican War on Science.

\section{ZOO NEWS}

\section{Hope and prey}

In case you were wondering, male praying mantises do know they could be eaten after sex, and they don't like the idea. Biologists at New York State University have found that males can assess how hungry females are: if the risk seems high, males approach more cautiously and mount from a greater distance. How exactly they manage the latter isn't clear.

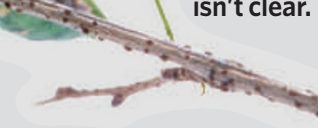

Pulling the wool...

The trial of disgraced stemcell scientist Woo Suk Hwang continues to amaze. He is accused of accepting 2 billion won (US\$2.1 million) in private donations, but Hwang insists none of it went to him personally. He told the court last week that part of the money was used in an attempt to clone mammoths.

\section{NUMBER CRUNCH}

How fast does the eye transmit information to the brain?

6 bits of information, at least, are sent every second by each cell in a guinea pig's optic nerve.

$\mathbf{8 7 5 , 0 0 0}$ bits are calculated to be sent each second by the whole nerve $\left(10^{5}\right.$ cells $)$.

$\mathbf{8}, 750,000$ bits would thus be sent every second by a human optic nerve... about the same as a standard Ethernet connection.

\section{SCORECARD}

$\checkmark$ Russian rockets A Dnepr rocket, based on the Soviet RS-20 missile, has crashed carrying 18 satellites, including 14 'microsats' made by students. NATO dubbed the original missile Satan; it's now being called worse names in classrooms around the world.

Sources: Time, Am. Nat., Curr. Biol.

\title{
NASA threatens to axe science on space station
}

\section{WASHINGTON DC}

In a move poorly received by key members of the US Congress, NASA last week said that it might shut down scientific research on the International Space Station for at least a year, to save money.

NASA is struggling to fund its mission to send astronauts back to the Moon, while spending around $\$ 200$ million a year on research in the station.

But Congress has mandated, as part of the 2005 NASA Authorization Act, that the agency should carry out "to the maximum extent practicable, basic, applied, and commercial research aboard the International Space Station". The act also specifies that NASA should allocate at least $15 \%$ of the funds budgeted for space-station research to experiments not directly related to the human exploration programme.

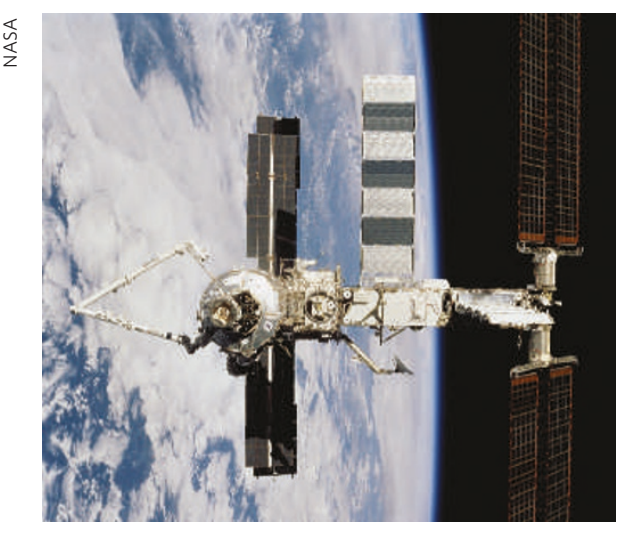

Lost in space: the space station is using up cash that NASA needs to fund its Moon mission.
"The International Space Station is first and foremost a space laboratory," says Katie Boyd, a spokeswoman for Senator Richard Shelby (Republican, Alabama). His state hosts the Marshall Space Flight Center, which manages science work aboard the space station. "To suggest that NASA would not take advantage of this unique laboratory is shortsighted."

A NASA spokesman, Grey Hautaluoma, said that he could not comment on ongoing budgetary discussions. "Right now, that funding is still there," he says.

About three dozen experiments are currently under way on the station, from biology set-ups that use the the astronauts as guinea pigs, to aeronautics experiments that use polyhedrons to test flight-control algorithms.

A year-long hiatus from research would mean more than missing data points. Restarting stalled projects will require staff to be rehired and equipment replaced. In the end, taking time off from research would probably cost more than it saved.

"I can't believe that they would discuss this with a straight face," says former NASA employee Keith Cowing, who broke the story on his website, NASA Watch.

Some of the 16 other partners in the station agree that the idea doesn't have legs. "If they were really going to, I think they would announce it to us first, before the press," says Marc Heppener, head of the station science programme at the European Space Agency. Heidi Ledford With additional reporting by Geoff Brumfiel and Jenny Hogan

\section{The proof is in the product}

It's pretty standard to find syntheses in a chemistry journal. But a paper published online last week by the international edition of Angewandte Chemie has got the world of organic chemistry humming. It is the second time this year that the journal has published a complete synthesis for a molecule called hexacyclinol - yet each paper claims a different structure for its final product.

Hexacyclinol is extracted from a mushroom and has some medical potential. The first synthesis of the molecule was published in February by chemist James La Clair of the Xenobe Research Institute in San
Diego (J. J. La Clair Angew. Chem. Int. Ed. 45, 2769-2773; 2006).

But La Clair's work raised a few eyebrows. For instance, he said his 37-step synthesis made 3.6 grams of hexacyclinol. "I've never heard of a synthesis of that length producing that much material," says Larry Overman, an organic chemist at 